\title{
The organizational fundamentals of innovation development management of agro-industrial enterprises
}

\author{
Ilona Yasnolob *, Yana Radionova ** \\ * Poltava State Agrarian Academy, \\ 1/3 Skovorody str., Poltava, 36003, Ukraine \\ PhD, Department of Business and Law \\ ** Poltava State Agrarian Academy, \\ 1/3 Skovorody str., Poltava, 36003, Ukraine \\ PhD Student, Department of Finance and Credit
}

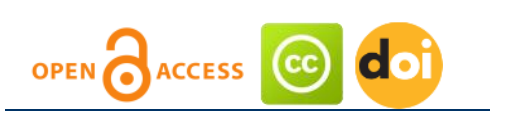

Article history:

Received: April 14, 2017

1st Revision: April 14,

2017

Accepted: April 30, 2017

\section{JEL classification: \\ L11 \\ L16 \\ L22 \\ 032 \\ 033 \\ P42}

\section{DOI:}

10.14254/jems.2017.2-1.5

\begin{abstract}
Modern prospects of innovation activities at agro-industrial enterprises and the conditions of innovation diffusion have been discussed. The main structure forming elements of organizing innovation activities have been characterized: personnel (people), ideas, funds, culture. The principles of organizing innovation activities at agro-industrial enterprises have been suggested. The functioning of these principles is provided by the project-matrix structure of the organization. It has been proven that the necessary conditions of effective organizing innovation activities at agro-industrial enterprises are: the distributing of roles and responsibilities; ensuring the effective distribution of information and flexibility of using resources; defining the responsibility for the made decisions. The practical importance of the investigation consists in developing concrete methodological foundations the using of which allows to raise the effectiveness of innovation activities at agro-industrial enterprises.
\end{abstract}

Keywords: innovations, innovation activities, development, planning, organization, agro-industrial enterprises, Global Innovation Index.

\section{Introduction}

At present, market transformations of Ukrainian economy induce economic subjects of agroindustrial complex to perform innovation activities in order to preserve the competitiveness of their products and services.

The results of statistical research of innovation active enterprises having positive increase dynamics during the last years confirm such a paradigm. For example, during 2015 the share of enterprises which performed innovation activities was 17.3\%, and the corresponding index in 2010 
was $13.8 \%$. The real volume of sold innovation products at agro-industrial enterprises has decreased by $1.3 \%$.

This testifies that the dominant of innovation activities at agro-industrial enterprises of Ukraine are non- technological, that is marketing and organizational innovations.

It is also necessary to mention that the position of Ukraine according to the international rating Global Innovation Index has the tendency to increasing from the $64^{\text {th }}$ place in 2015 to the $56^{\text {th }}$ in 2016, though in the frames of Innovation Efficiency Ratio which characterizes the creation of special conditions for assisting in achieving innovation results, in 2016 Ukraine occupies the $12^{\text {th }}$ place out of 128 countries under investigation. This helps to improve investment attractiveness of the country in future.

The presence of such balance in the ranks as to the main indices of activeness and practical implementation of innovation activities characterizes permanent under-utilization of the possibilities of innovation growth and the presence of state regulation problems, and the organization of innovation activities of economic subjects in agro-industrial complex.

Francis Garry, Director general of WIPO and Bruno Lanvin, the director of business school INSEAD paid special attention to the globalization of innovation networks during press-conference "Victory with global innovations".

Taking into account all the above mentioned facts, China together with the developed countries are creating an international platform for the globalization of innovations that is the latest tendencies of international management structure are increasing the share of innovation technologies' diffusion into developing countries (Xiaoxun, 2016).

That is why Ukraine faces not only the prospects for developing, but also the risks connected with the stability and sustainability of this development. Thus, the necessity arises concerning working out the mechanism of organizing innovation activities of economic subjects in agroindustrial complex.

During the investigation, the methodological basis are the following scientific methods: historical-dialectical (for determining and analyzing market transformations of innovation activities, the contents of its planning and management), of analysis and synthesis (for revealing the problems of the organization of innovation activities), theoretical search and abstract-logical (for characterizing the content filling of the components of organizing innovation activities), modeling (for making the successive form of organizing innovation activities).

Organizational-economic aspects of investigating the problems of innovation activities at agro-industrial enterprises have been considered in the publications by such modern Ukrainian scholars as V.H. Andriichuk, I.M. Boichyk, O.I. Volkov, T.H. Duhar, O.Yu. Yermakov, B.F. Zablotsky, V.I. Zakharchenko, S.M. Illiashenko, P.P. Mykytiuk, A.V. Shumsky.

The activities of agro-industrial enterprises are based on uniting the production of agricultural products with their further industrial processing, finishing, and storing. Agro-industrial enterprises have the united body for organizing the effective activities of internal economic subdivisions which legally are not independent and have the balance and plan of social-economic development common for all the kinds of activities (Andriichuk, 2002).

That is why the effectiveness of innovation activities at agro-industrial enterprises is directly proportional to the organization of the process of implementing innovation decisions (Zakharchenko, 2012).

Ukrainian scientists consider the organization as a process directed at the most rational uniting of material, power, labor, financial, informational resources in the production process, the result of which is overall uniting of all resources and their further using (Nebava, 2011).

The main aspects of organizing innovation activities at agro-industrial enterprises are: organizational structure and the process of regulating innovation process.

Organizational structure is the totality of scientific, construction, project, technological, informational subdivisions which perform basic creative activities aimed at creating innovations and production, subsidiary, and managerial subdivisions that provide performing the plans of research and construction work, and implementing innovation projects.

The process of putting in order innovation activities is made through regulating procedures of methods, forms, processes which are used in the process of innovation activities.

Taking into account modern economic conditions and the results of scientific and technical progress the organization of innovation activities at agro-industrial enterprises is to be based on decentralization and independence of subdivisions which in the future will provide high activeness, mobility of organizational forms and plurality of products and services, new methods, technologies, management structures.

Nevertheless, considering the specifics of agro-industrial enterprises' activities and the environmental conditions, the organization of innovation activities must include the processes of integration and diversification. The integration of the organization of agro-industrial enterprises' 
activities is oriented at activation of scientific-research and production processes, and diversification - at eliminating the drawbacks of internal and inter-firm integration processes and is directed at new technologies and highly technological production as to all the directions of activities.

The theoretical background of investigating the questions of innovation theory and innovation management have been covered in the works by such foreign scientists as B. Twiss, Joseph Alois Schumpeter Maria Barbera, Paul Trott, Tony Davila, Peter Drucker, Ravi K. Jain, Richard Milhous Nixon, Shlomo Maital, Walter Eversheim.

The attention should also be paid to the fact that foreign researchers consider the organization of enterprise's innovation activities from the viewpoint of their main components, such as People, Ideas, Funds, Culture) (Jain, Triandis, \& Weick, 2010).

For example, the People of innovation enterprise have to obtain a $\mathrm{PhD}$ degree and have comparatively viabilities and skills to work autonomously showing a considerably higher initiative. Ideas are generated owing to unique network connections which have the character of scientific community. Funds are considered as a financial support from the Federal government for providing enterprise's innovation activities, that is, financing innovation activities must be provided with the money from the state budget (Jain, Triandis, \& Weick, 2010).

Obviously, creative people are the most important element of organizing innovation activities. Such people have bright ideas and skills to make investigations and then use the results of investigations for making useful products. But these people must be organized into structures which will provide effective cooperation. It should be kept in mind that some unions of people work better than others. For providing proper organization it is necessary to possess suppositions, persuasions, norms, values, and others. In other words, it is necessary to create such an organizational structure, which will assist in creativity and innovations. And last, but not least, money is necessary for financial providing of innovation activities (Jain, Triandis, \& Weick, 2010).

The category "organizing innovation activities" is treated in foreign literature as "organizing innovations" (Eversheim, 2009). For example, organizing innovations as a structural and strategic component of innovation management forms the frames for planning and control of enterprise's innovation activities. Insufficient scientific elaboration, urgency, and practical demand of namely this scientific direction have caused the choice of the topic and statement of the problem, target direction and structural composition of our research.

Nevertheless, in spite of considerable amount, a number of problems need to be further investigated. In particular, these are the questions of organizing innovation activities at agroindustrial enterprises in the conditions of the increasing degree of risk and indefiniteness.

The main aim of the article is investigating the conceptual foundations of the process of organizing innovation activities at agro-industrial enterprise. So, the following tasks have been set and solved in the given research: to investigate theoretical and methodical foundations of organizing innovation activities at agro industrial enterprises by studying national and foreign experience, taking into account the specific features of their work; to develop the successive model of the management of organizing innovation activities at agro-industrial enterprises; to determine the main structure forming elements, functions of the process of organizing innovation activities at agro-industrial enterprises; to formulate the consecutive order of the process stages of organizing innovation activities at agro industrial enterprises; to single out the optimal structure of the management of agro-industrial enterprises under the conditions of constant innovation introduction.

\section{Methodology}

The methodology of the conducted research was based on system-activity approach, which provides the possibility to consider the process of organizing innovation activities at agroindustrial enterprises as a separate great number of elements, which will ensure the opportunity to determine mutual connections among them. In particular, the methodical bases of the research are the following: critical analysis (for investigating the scientific literature in the field of innovation activities, its organization); structuring (for describing the components of the process of organizing innovation activities at agro-industrial enterprises); functional (for singling out the main functions of the process of organizing innovation activities at agro-industrial enterprises); informational (for investigating the informational aspects of the process of organizing innovation activities at agroindustrial enterprises); modeling (for showing the successive stages of the process of organizing innovation activities at agro-industrial enterprises); graphical method (for reflecting the projectmatrix structure of the management of innovation activities at agro-industrial enterprises). 


\section{The form and structure of organizing innovation activities at enterprises of agro-industrial enterprises}

The formation of the organization system in innovation development of agro-industrial enterprise is guided by the implementation of the directions and variants of innovation development, which are revealed as a result of the system of prognostication and planning functioning. In the innovation activities at agricultural enterprise the system of organization provides the fulfillment of the following main functions (Fig. 1) (Zablotsky, 2007).

Figure 1: The main functions of the system of organizing innovation activities at agroindustrial enterprises

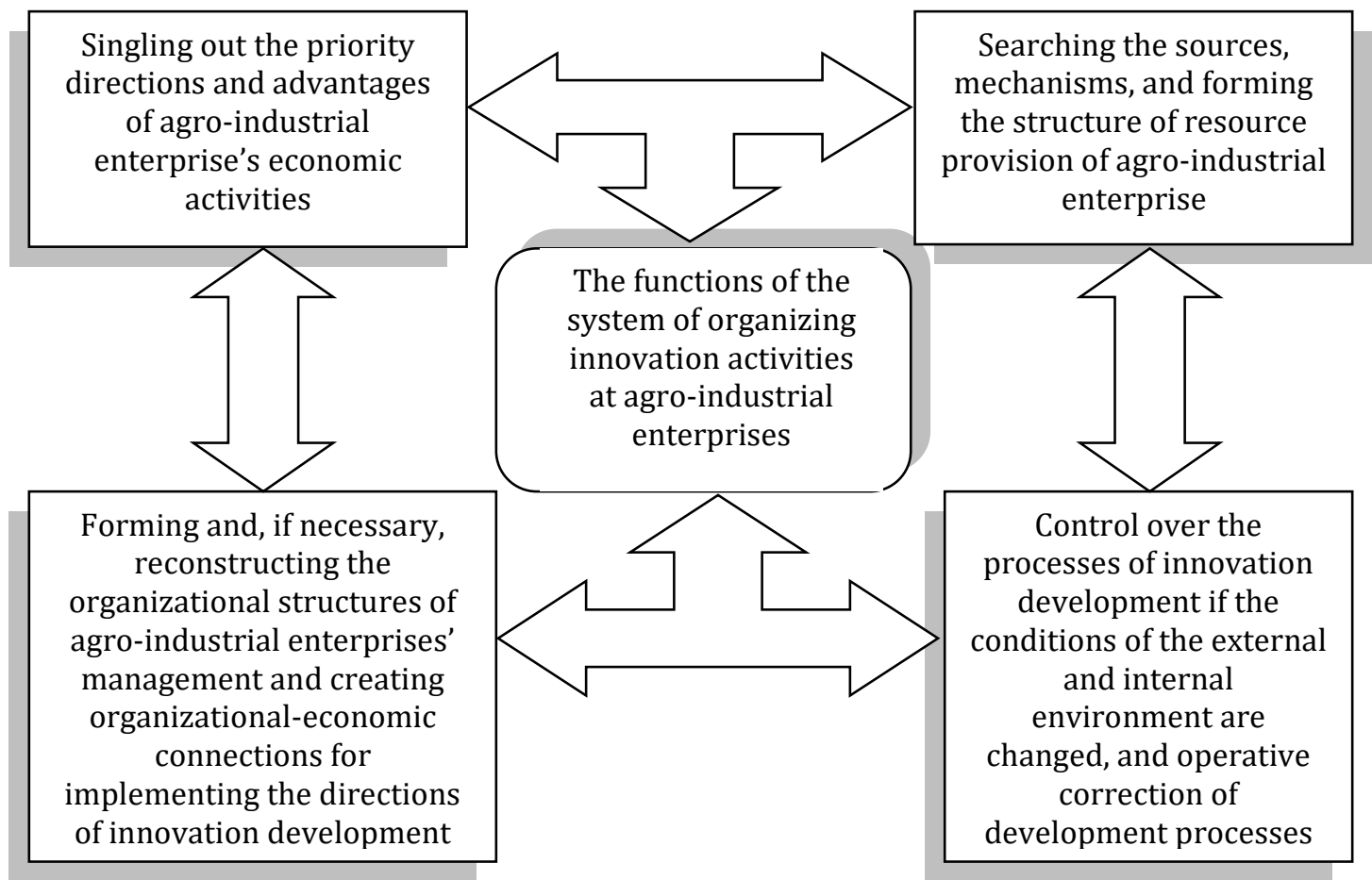

The main aim of organizing innovation activities is to create the structure which will provide the optimal innovation ability of enterprise.

Consequently, taking into account the theoretical aspects put forward by Ukrainian scientists and the peculiarities of organizing innovation process mentioned above by the foreign scholars, the author has formulated the main practical propositions for the effective organizing innovation activities of agro-industrial enterprises in Ukraine (Fig. 2).

The pivotal stages of organizing innovation activities at agro-industrial enterprises, considering their aim, are stating the tasks to executors, exchanging information, budgeting, and distributing resources.

The stage of stating the task to executors includes the formation of corresponding organizational structure that is the distribution of rights, duties, and responsibility, and also the order and forms of interaction among all the structure forming the units of agro-industrial enterprises.

As it is known, there are two ways of exchanging information: advance and defense. The advance type of information exchange is characterized by open internal relations inside the enterprise and bilateral processing information concerning the external environment, and the defensive type consists of unilateral, secret agreements in the internal and external environments of agro-industrial enterprises' functioning.

The volume of budgeting is aimed at either independence (autonomy) or connection. That is, the autonomous structure is characterized by the fixed annual budget of innovation planning, and connected budgeting appears as a result of oriented demand on annual budget.

The distribution of resources relatively to the personnel and time is integrated (general planning of innovation activities) or differentiated (it concerns isolated innovation projects).

The organization of innovation activities' development at agro-industrial enterprises must be performed considering the corresponding principles. 
Figure 2: The successive form of organizing innovation activities at enterprises of agroindustrial enterprises

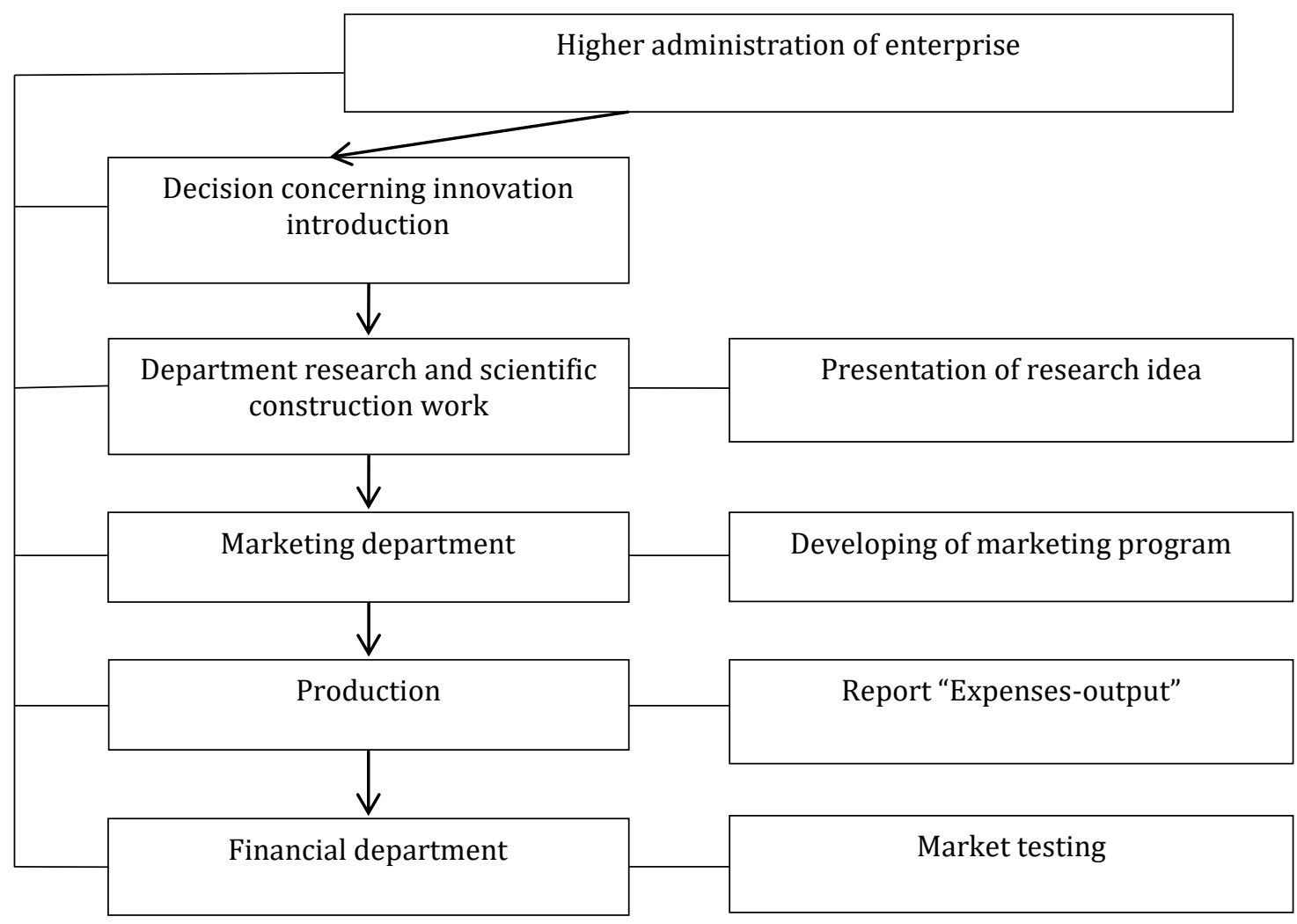

Note: If agro-industrial enterprise introduces product innovation, after the stage of "Production" it is necessary to make calculations of expenses. These calculations are made by "Sales department".

The main principles of organizing innovation activities at agro-industrial enterprises are the following ones: the principle of the first manager, the principle of collective nature, the principle of authorship, the principle of personal responsibility, the principle of permanent innovation introduction, the principle of balance between current and innovation activities.

The principle of the first leader means that each innovation project is to have its own first manager who takes part in developing and starting an innovation.

The principle of collective nature presupposes the stage of group work, collective nature, and responsibility for making decisions concerning innovation activities.

The principle of authorship means attracting the future executors of innovation projects to developing the decisions of the given innovation; this principle will ensure the probability of innovation seizure and improve its introduction into enterprise's activities.

The principle of personal responsibility means that each innovation must have its leader who has personal responsibility for the quality of innovation development and the success of its introduction.

The principle of permanent innovation introduction. Considering modern economic conditions innovation activities must have constant and permanent character. The principle of balance between current and innovation activities includes the simultaneous engagement in innovation, current, and strategic activities of agro-industrial enterprise.

The implementation of the above mentioned principles of organizing innovation activities at agro-industrial enterprises is performed through the project (matrix) structure of management (Fig. 3).

The project-matrix structure of management presupposes attracting the personnel to the main current activities and the innovation project, and this structure has a temporal character.

According to the project-matrix organization of innovation activities' management at agroindustrial enterprises, the employees of functional and line subdivisions are subordinate to the project manager during the term of performing the innovation project, that is the transfer of constant subdivisions to the project group takes place. The head of the innovation project distributes the tasks, controls, and coordinates the work of executors, providing them with technical information. 
Figure 3: Project-matrix structure of organizing innovation activities at agro-industrial enterprises

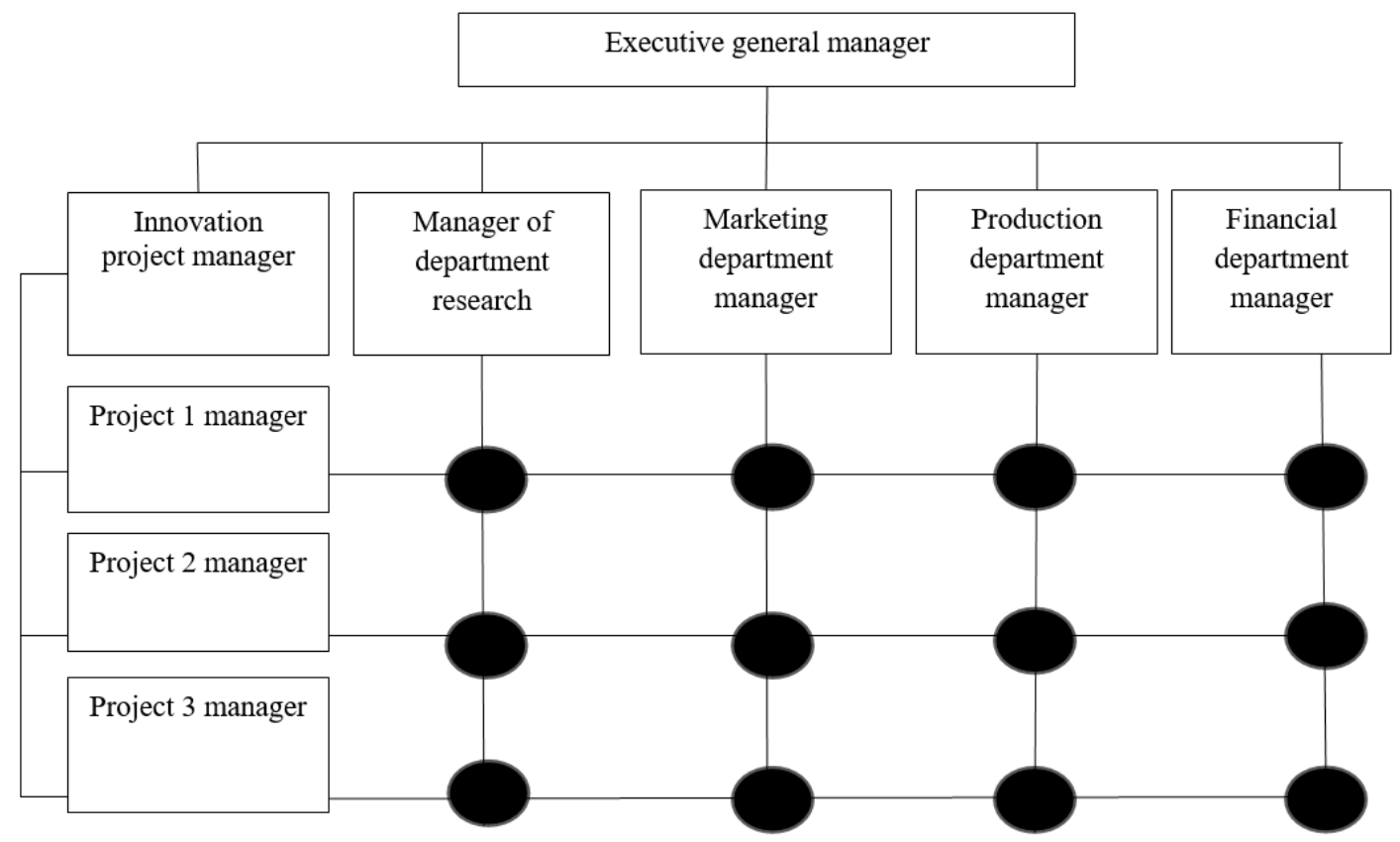

Note: - project-target groups.

Source: author built.

So, the necessary condition of the effective organization of innovation activities at agroindustrial enterprises is providing the interaction of the participants of innovation process; distributing roles and responsibility; providing the effective distribution of information and the flexibility of using resources; determining the responsibility for the made decisions.

\section{Conclusions}

Thus, the concept of organizing innovation activities at agro-industrial enterprises suggested above includes such aspects as organizational structure and the process of regulating the innovation process. So, the peculiarity of the process of regulating innovation activities at agroindustrial enterprises is the orientation toward decentralization and independence of the subdivisions of innovation project.

Positioning the tasks to the executors, exchanging information, budgeting, and distributing resources are the main stages of the effective organization of innovation activities at agro-industrial enterprises in modern conditions. The implementation of the main stages and principles of organizing innovation activities at agro-industrial enterprises is provided by the project-matrix organizational structure.

The new type of organizing innovation activities at agro-industrial enterprises includes the processes of integration (making more active scientific-research and production processes) and diversification (eliminating the drawbacks of internal and inter-firm integration processes).

Further research should be directed at developing and scientific substantiating the mechanism of organizing and organizational structures of the management of innovation activities at agro-industrial enterprises.

\section{Appendix A. Supplementary material}

Supplementary data associated with this article can be found, in the online version, at http://dx.doi.org/10.14254/jems.2017.2-1.5

\section{Funding}

The authors received no direct funding for this research. 


\section{Citation information}

Yasnolob, I., \& Radionova, Ya. (2017). The organizational fundamentals of innovation development management of agro-industrial enterprises. Economics, Management and Sustainability, 2(1), 60-66. doi:10.14254/jems.2017.2-1.5

\section{References}

Andriichuk, V. H. (2002). Economics of agrarian enterprises (2nd ed.). Kyiv: Kyiv National Economic University Pub.

Ceylan, C. (2013). Commitment-based HR practices, different types of innovation activities and firm innovation performance. The International Journal of Human Resource Management, 24(1), 208-226. doi:10.1080/09585192.2012.680601.

Eversheim, W. (Ed.). (2008). Innovation management for technical products: systematic and integrated product development and production planning. Springer Science \& Business Media.

Fung, K. C., Aminian, N., \& Tung, C. Y. (2016). Some characteristics of innovation activities: Silicon Valley, California, China and Taiwan. Economic Change and Restructuring, 49(2-3), 221-240. doi:10.1007/s10644-015-9162-x.

González-Pernía, J. L., Peña-Legazkue, I., \& Vendrell-Herrero, F. (2012). Innovation, entrepreneurial activity and competitiveness at a sub-national level. Small Business Economics, 39(3), 561574. doi:10.1007/s11187-011-9330-y.

Jain, R., Triandis, H. C., \& Weick, C. W. (2010). Managing research, development and innovation: Managing the unmanageable (Vol. 34). John Wiley \& Sons.

Jha, A. K., \& Bose, I. (2016). Innovation in IT firms: An investigation of intramural and extramural R\&D activities and their impact. Information \& Management, 53(4), 409421.doi:10.1016/j.im.2015.09.002.

Khaustova, K. M. (2016). Estimation the impact of macroeconomic factors on the innovation activities of enterprises in Ukraine. Marketing and Management of Innovations, 46(4), 184198. doi:10.15838/esc/2016.4.46.10.

Mettens, P. (2012). Open innovation and the relation between innovative activities and firm performance. Managing Open Innovation: Connecting the Firm to External Knowledge. Cheltenham: Edward Elgar Publishing Ltd.

Nebava M. I., Adler O. O. \& Lesko O. Y. (2011) Economics and Organization of Enterprise's Production Activities. Part 1 (Economics of Enterprise). Vinnytsia: VNTU Pub.

The Global Innovation Index. $\quad$ (2016). Retrieved from https://www.globalinnovationindex.org/analysis-indicator

The State Statistical Service. (2016). Retrieved from http://ukrstat.org/uk/operativ/operativ2005/ni/ind_rik/ind_u/2002.html

Trott, P. (2008). Innovation management and new product development. Pearson education.

Xiaoxun, L. (2016). Innovations drive best path to sustainable economic growth. Retrieved from https://www.newsghana.com.gh/innovation-drive-best-path-to-sustainable-economicgrowth/

Zakharchenko, V. I., Korsikova, N. M. \& Merkulov, M. M. (2012). Innovation Management: Theory and Practice in the Conditions of Transformation. Kyiv: Center of study literature

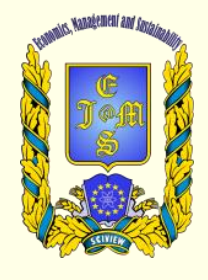

(c) 2016-2017, Economics, Management and Sustainability. All rights reserved.

This open access article is distributed under a Creative Commons Attribution (CC-BY) 4.0 license.

You are free to:

Share - copy and redistribute the material in any medium or format Adapt - remix, transform, and build upon the material for any

purpose, even commercially.

The licensor cannot revoke these freedoms as long as you follow the license terms.

Under the following terms:

Attribution - You must give appropriate credit, provide a link to the license, and indicate if changes were made.

You may do so in any reasonable manner, but not in any way that suggests the licensor endorses you or your use.

No additional restrictions

You may not apply legal terms or technological measures that legally restrict others from doing anything the license permits.

Economics, Management and Sustainability (ISSN: 2520-6303) is published by Scientific Publishing House "CSR",

Poland, EU and Scientific Publishing House "SciView", Poland

Publishing with JEMS ensures:

- Immediate, universal access to your article on publication

- High visibility and discoverability via the JEMS website

- Rapid publication

- Guaranteed legacy preservation of your article

- Discounts and waivers for authors in developing regions

Submit your manuscript to a JEMS at http://jems.sciview.net or submit.jems@sciview.net

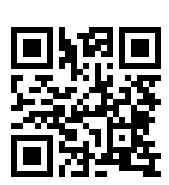

